Meta

Journal des tradlucteurs

Translators' Journal

\title{
What's the Difference?
}

\section{Maureen Hole}

Volume 23, numéro 2, juin 1978

URI : https://id.erudit.org/iderudit/003077ar

DOI : https://doi.org/10.7202/003077ar

Aller au sommaire du numéro

Éditeur(s)

Les Presses de l'Université de Montréal

ISSN

0026-0452 (imprimé)

1492-1421 (numérique)

Découvrir la revue

Citer cet article

Hole, M. (1978). What's the Difference? Meta, 23(2), 161-163.

https://doi.org/10.7202/003077ar

Ce document est protégé par la loi sur le droit d'auteur. L’utilisation des services d'Érudit (y compris la reproduction) est assujettie à sa politique d'utilisation que vous pouvez consulter en ligne.

https://apropos.erudit.org/fr/usagers/politique-dutilisation/
Cet article est diffusé et préservé par Érudit.

Érudit est un consortium interuniversitaire sans but lucratif composé de l’Université de Montréal, l'Université Laval et l'Université du Québec à Montréal. Il a pour mission la promotion et la valorisation de la recherche. https://www.erudit.org/fr/ 


\section{WHAT'S THE DIFFERENCE ?}

Most trades develop their own jargon, often unintelligible to the layman and often spotted with a plethora of terms which seem to be synonymous and interchangeable. The weavers are no exception, as we find in their speech five terms to express two concepts. Two of them, "warp » and "ends 》 supposedly refer to «the threads which run lengthwise and parallel to the selvage $\gg$ in a woven fabric whilst « filling》, «picks》 and «weft» are used to identify «the threads which run crosswise from selvage to selvage ». Are all these terms really used interchangeably, or can a fine line be found to distinguish between them ?

In order to find the answer we turn to a number of textiles dictionaries and textbooks, where it is discovered that the terms «warp 》 and «filling 》 appear to be the most commonly used. They are to be found in almost all passages defining or dealing with these two concepts in the sources studied. They appear at the head of any lists of synonyms given and are used in preference to these synonyms throughout the rest of the texts.

"Ends », the only alternative suggested for « warp», does not seem to have quite the same meaning, nor generally to be used interchangeably with it. All sources which made reference to the term did so in the singular and defined it as being one single warp thread. In other words, the threads which run parallel

19. Larousse, op. cit., vol. 4, entrée : fils. 
to the selvage are known collectively as the warp and individually as ends. Thus one may say that «the warp is stretched in parallel lines in the loom and certain parts of it are raised and depressed to allow the shuttle to pass », but that a certain weave « is repeated over two ends and two picks》.

The term «picks» is to filling as « ends » is to warp; a pick, of course, refers to one individual thread. Picks and ends seem to have come to mean collectively the threads which run "crosswise from selvage to selvage 》 and «lengthwise and parallel to the selvage » respectively, despite the collective nouns 《filling» and «warp » which already existed. By the same token, one often hears « warp threads » or « filling yarns , instead of ends and picks, to refer to the individual threads. The terms « ends » and « picks» do not appear to be in common use today, although one source did state that they are frequently found in industry.

The term «weft , a collective noun meaning « the threads that run crosswise from selvage to selvage » is chiefly a British equivalent for «filling . In England « filling 》 refers solely to the material added to fabric to improve weight or appearance, whereas in North America it may have both of the above meanings. Some sources consider «weft 》 and «filling 》 to be more or less interchangeable, but generally speaking, «weft» is only used in North America in the carpet trade and in hand-weaving. The term is sometimes found in advertising, as it is thought to add a certain English flair which may attract the attention of the consumer.

In general terms, one may distinguish between «warp 》 and « ends 》 and 《 filling 》, «picks » and «weft » as follows :

warp : the threads which run lengthwise and parallel to the selvage in a woven fabric ;

filling: the threads which run crosswise from selvage to selvage in a woven fabric ;

ends : individual threads, which collectively compose the warp ;

picks : individual threads, which collectively compose the filling;

weft : the British equivalent of filling.

MaUReen Hole

\section{BIBLIOGRAPHY}

COLLIER, A.M., A Handbook of Textiles, Pergamon Press, Oxford, 1970.

A Dictionary of Textile Terms, 11th ed., Dan River Inc., New York, 1971.

Encyclopedia of Textiles, 2nd ed., American Fabrics Magazine, Prentice-Hall, Inc., Englewood Cliffs, New Jersey, 1973.

HAMBY, DAME S., The American Cotton Handbook, 3rd ed., Interscience Publishers, New York, 1966, vol. II.

LINTON, G., The Modern Textile and Apparel Dictionary, 4th ed., Textile Book Service, New Jersey, 1973. 
POTTER, D. and CORBMAN, B., Textiles: Fiber to Fabric, 4th ed., McGraw-Hill Book Company, New York, 1967.

PRESS, J., Man-made Textile Encyclopedia, Textile Book Publishers, Inc., New York, 1959. STOUT, E., Introduction to Textiles, 3rd ed., John Wiley and Sons, Inc., New York, 1970. Textile Handbook, 4th ed., American Home Economics Association, Washington, 1970. Textile Terms and Definitions, 6th ed., The Textile Institute, Manchester, 1972.

WEFORD, T., The Textile Student's Manual, 6th ed., Sir Isaac Pitman and Sons, Inc., London, 1966.

WINGATE, I., Fairchild's Dictionary of Textiles, Fairchild Publications, Inc., New York, 1967. 